\title{
Governance in the Legislative Power: looking at the parliamentary boards
}

\author{
André Rehbein Sathler Guimarães \\ Câmara dos Deputados \\ Fabiano Peruzzo Schwartz \\ Câmara dos Deputados
}

Ricardo Corrêa Gomes

Universidade de Brasilia (UnB)

The paper analyses governance in the parliamentary boards using a quali-quantitative research. The analysis is based on corporate governance to identifying differences and similarities on public governance in the Legislative Power. We collected data from several different types of parliamentary boards. A quantitative and comparative model is presented to assert the level and kind of governance in legislative bodies, specifically the type of governance exerted by parliament's boards. Findings reveal great heterogeneities demonstrating that each parliament comes up with a specific solution for its governance problems. The main theoretical contribution of the paper is that the legislative power is so idiosyncratic to copy standardized solutions.

Keywords: legislative power, governance, public administration

\section{Governança no Poder Legislativo: um olhar para as mesas dos parlamentos}

O artigo analisa a governança em parlamentos, com uso de métodos quali-quantitativos. A análise parte de conceitos de governança corporativa, para identificar diferenças e semelhanças com o processo de governança pública no Poder Legislativo. Foram coletados dados a respeito de diversas mesas diretoras em parlamentos. Um modelo quantitativo e qualitativo é desenvolvido para avaliar o nível e o tipo de governança em corpos legislativos, especificamente o tipo de governança exercido pelas mesas diretoras. Os achados demonstram grande heterogeneidade, revelando que cada parlamento desenvolve uma solução própria para suas questões de governança. A principal contribuição teórica é que o Poder Legislativo necessita de soluções específicas de governança, dadas suas idiossincrasias.

Palavras-chave: poder legislativo, governança, administração pública

[Artigo recebido em 19 de abril de 2016. Aprovado em 7 de abril de 2017.] 


\section{Gobernanza en el Poder Legislativo: una mirada a las mesas de los parlamentos}

El artículo analiza la gobernanza en parlamentos, con el uso de métodos cuantitativos. El análisis parte de conceptos de gobierno corporativo, para identificar diferencias y semejanzas con el proceso de gobierno público en el Poder Legislativo. Se recogieron datos sobre varias mesas directivas en parlamentos. Un modelo cuantitativo y cualitativo se desarrolla para evaluar el nivel y el tipo de gobernanza en cuerpos legislativos, específicamente el tipo de gobernanza ejercido por las mesas directivas. Los hallazgos demuestran gran heterogeneidad, revelando que cada parlamento desarrolla una solución propia para sus cuestiones de gobernanza. La principal contribución teórica es que el Poder Legislativo necesita soluciones específicas de gobernanza, dadas sus idiosincrasias.

Palabras clave: poder legislativo, gobernanza, administración pública 


\section{Introduction}

This paper aims to shed an investigative glance over the Legislative Power governance, as a branch of the public administration, focusing particularly the issue of the directorate board in parliamentary institutions. The investigation seeks to understand the governance phenomenon in the Legislative Power under two perspectives: political and managerial. The emphasis on the role of the board is due to the fact that this is the locus of the governance processes, according to the literature. Besides, classical studies about parliament and its institutionalization processes, such as Polsby (1968), suggests that the boards are important as indicator of the differentiation between the organization and its environment. For so doing, we undertook a comparative analysis combining quantitative and qualitative methods.

In this paper, we aim to answer the following research question: what is the role of the directorate board in the parliament governance? To this end, we carried out the investigation with some differentiating perspectives and some advancements on theory and practice. The differentiating perspectives are related to the objective of analyzing public administration in the Legislative Power institutions emphasizing aspects of governance. The Legislative Power, although inserted in the government strategic core, is widely underexplored in academic studies in the field of public administration, although there are some specific aspects of the legislative public administration. Another perspective that differentiates this research from others is that it aims to demonstrate how governance systems affect the dynamic of other sectors of the Legislative House. As a contribution, we developed a two-dimensional model to classify the legislative houses according to the role of the directorate board in the governance system. The model allows an easy understanding, comparative analysis, and the depicting alternatives for improvement. In addition, the model allows generalization on replicating this framework to similar studies on other organizations. More than distinguish between boards that were responsible for legislative process (e.g. a rules committee) versus those responsible for internal expenditure and operations (e.g. a board of an internal economy), this is a tentative to show how Boards affects the general guidance in the Houses. And the scenarios developed try to show a political inclination vis a vis an administrative perspective.

The history of legislative body boards is as old as the history of the democratic gatherings. It is based on the remote notion that there isn't vacuum in power, associated to the material impossibility of keeping an assembly gathered all the time. There are some interpretations that the mythologies and its pantheons have inspired the men imprinting mental models that shaped, structured and energized people's life allowing the construction of meaning systems (KEANE, 2010). The gods gathered for making decisions and there were the circle of the most powerful deities, 
who were in charge to decide about what decisions should be made. In the case of people from Syria and Mesopotamia, for instance, "there was about fifty gods and goddesses, but the most important instructions were set down in small assemblies of seven" (KEANE, 2010, p. 132, free translation) ${ }^{1}$. The competence of deciding what should be decided (agenda setting) is of great importance, especially in the political houses in which the power to establishing the agenda is very relevant.

Immerse in mystical thoughts, those people assumed that imitating the selfgovernment methods of their deities was a mean for absorbing their qualities. Due to this, they emulated the process of gathering together to make collective decisions. From compromises reached by consensus, the prevalent power reproduced the religious structure of the pantheon through transfiguration mechanisms.

In Athens, the democratic experience of the antiquity became more famous, there was the Council of the Five Hundred, which was permanent, while the assembly was normally gathered for just one day, forty times a year, ten days in a row, or about four times a month in the Athenian civil calendar of ten months (KEANE, 2010). This Council of Five Hundred, labeled as Boulé, had the responsibility of organizing the agenda to be discussed by the assembly, and, it was responsible for conducting the work. Furthermore, it was also responsible for overseeing the Ekklesia decisions.

When the parliaments became common in Europe, around the 17 century, with the summon of Lion Courts in March 1188, by Alfonso IX, the practice of boards also came back - "the courts appointed a committee, the disputación permanente, which had the functions of monitoring the management of public funds and ensuring that the laws were equally complied by the Crown and by its subjects" (KEANE, 2010, p. 185 , free translation). Created for the interregnum, the boards are the parliaments in vigilando. From this historic beginning they remain as a fundamental element of the Legislative Power governance.

\section{Theoretical framework}

In this research we employ knowledge from the organizational institutionalism (Aguilera; Cuervo-Cazurra, 2004; Aguilera; JaCkson, 2003; CAPron; Guillén, 2009; EnRIONE; MAZZA; Zerboni, 2006; ZATTONI; CuOMo, 2008), which has in its concerns the diffusion of organizational practices and the issue of legitimacy, being governance a strong legitimating element for the institutions. These institutions as

\footnotetext{
1 Jacobsen $(1943,168)$ provides another example for the deific circles and explores the translation of these concepts to the politic world: "the fifty senior gods sat down, and the seven gods of fates fixed fates for Markuk [...] translating these mythical concepts into 'political' terms, we must define the seven gods 'who determine destiny' as gods whose words are 'authoritative' or 'decisive'".
} 
social structures are embedded in wider institutional and legal arrays in which both the result of the organizational practices, and the articulation axis for legitimacy are highly contingent (ROSSONI; MACHADO DA SILVA, 2010).

Somehow, the paper dialogues with the institutionalism literature. There are evidences of path dependence in the boards trajectory, as demonstrated by Braga, Sathler and Miranda (2016). And one of the points of the argument is just that institutions matters, or, that the boards, as institutions, matters. This perspective can be found in Hall and Taylor (2003) and in March and Olsen (1995). When comparing parliaments and companies, there is also a good proxy in the work of Weingast and Marshall (1988). But the choice is to explore more the administration perspective, or organizational institutionalism.

Taking into account the governance concept originated in the business sector, the high majority of studies have concentrated on the agency problem of the relationship between agent (CEO), and principal (shareholders). In the particular case of the public sector, this sort of questions needs to be seen as multilevel. For this reason it is important to investigate the means of incorporating business-based governance practices in public sector institutions, particularly in parliaments. The understanding of the role of directorate boards in the parliament governance processes requires retrieving well defined concepts from the business sector in order to calibrate the necessary adaptations to the field of legislative public administration.

In the private sector, governance is defined as a set of juridical, cultural, and institutional frames that defines what the company can do, who is entitled for making decisions, the way power is exercised and the amount of risks and incomes involved in the activities (BLAIR, 1995).

The single replacement of the word "company" for "parliament", in our vision, is enough for making the application feasible for our study. The "Instituto Brasileiro de Governança Corporativa" (Brazilian Institute for Corporate Governance - IBGC) provides a wider concept for governance: "a system through which organizations are managed, overseen and induced involving the relationship among owners, administrative board, directorate, and control bodies" (INSTITUTO BRASILEIRO DE GovernanÇA Corporativa, 2009, p. 19, free translation).

According to Matias-Pereira (2010, p. 224, free translation), "the analysis of the causes that led to conception and application of the corporative governance to the public sector is an evidence that the Brazilian State is trying improve its organization in order to make it more efficient and effective". This challenge became more important and timely in the extent that countries have been facing difficulties from the increase in the service and public policies demand, and a decrease in the tax collection (fiscal crisis). The "Tribunal de Contas da União" (Brazilian Federal Court of Accounts - TCU), in recent publication about public sector governance, suggests, 
"governance in the public sector encompasses the mechanisms of leadership, strategy, and control put to practice for assessing, orienting, monitoring managerial performance, looking at conducing public policies, and the delivery of service of interest of the society" (BRASIL, 2013, p. 26, free translation). In sum, governance is the governmental policies modus operandi.

Besides governance being a concept and not a managerial technology, we understand that its transposition to the public world should be done according to a process of managerial reduction, as suggested by Bergue (2011). That means the concept needs to be grasped in its substance (content), recreated and resignified through a reflection on its assumptions generating a new synthesis (use to the public sector). In this study, we also intend to propose a contribution by "undertaking a wide reflection process about the essential content of the cultural objectives being transplanted" (BERGUE, 2011, p. 316, free translation), particularly in the case of the governance concept. Parliaments are complex institutions and its operations are determined by a set of juridical frameworks, and cultural and institutional arrays. As a kind of public institutions, parliaments are subject to the scrutiny of the society. Furthermore, they encompass agency-based relationships, which seems the case of the relationship between politicians and managers, and between managers and other employees.

An essential difference between public and private governance is that in the private sector there is an ethos with no publicist content - the aim of aggregating economic value is eminently instrumental ${ }^{2}$. In the public sector, publicity is the main orientation and the governance process should be finalistic (SIMÕES, 2003). In parliaments, the legitimacy requirements of the decisions orbit around the public interest and around the process of formation and expression of the institutional will.

Private enterprises are voluntary associations of natural people and all other people and entities [stakeholders] that come across with the corporation do it in voluntary way. Public institutions, as parliaments, operate under a special apparatus with instrumental authority enacted by the State. The challenge of the governance in such cases is to find the means for improving the probability for the institution functions in ways that are not inconsistent with its main public objectives. The public governance model needs to articulate the institutional-administrative, the socio-politics, and the economic-financial dimensions in order for the managerial process and the institutional functioning contributes to the materialization of the

\footnotetext{
${ }^{2}$ In spite of the social responsibility rhetoric and of the stakeholder theory approach "at the end, the highest motivation for demanding a ethic-moral behavior from managers, in a higher scope rather than the exclusive segment of the people making actions, it to generate more wealthy to the company" (SIMÕES, 2003, p. 46, free translation).
} 
democracy as a collective patrimony. Worthy to recall that in the genesis of the governance concept there are structural and functional concepts of the capabilities system (SANTOS, 1997).

The higher level of the hierarchy and the decision system related to it is the focus of the governance. It is at the organization's apex that we can assess the whole scope of the governance concept. However, if in the private world one of the main governance questions is related to sharing authority between the administrative board and the CEO, on one side, and stockholders, on the other side ${ }^{3}$; in the case of parliaments the emphasis is placed over the separation between political control and administrative control, which is the core of the model.

The directorate board plays a central role in the relationship between politics and administration. The parliamentary systems have peculiar characteristics that contribute to stress the importance of the boards: existence-occurrence ${ }^{4}$, isegory and collective decision-making. These features will defend representative's interests (politics) before bureaucracy (administrative), and parliaments before society. As a result, the governance exerted by the boards has as an object the nature of the interactions and relationships between the Institution and its multiples stakeholders in the decision-making processes, and control over institutional resources. The boards need to solve coordination problems, as well as managing uncertainty, which are big in complex institutions such as parliaments while copying with strategic decisions. Its role, therefore, is to provide solutions for the problems, to reduce complexity, to create accountability and to facilitate cooperation and coordination among stakeholders. In this sense, the boards works similarly to administrative boards in corporations in terms of governance perspectives according to the extant literature (VAN EES; GABRIELSSON; HUSE, 2009, p. 308).

Consistent with this idea in terms of the role of the boards, according to Van Ees, Gabrielsson, and Huse (2009, p. 309), it can be defined as "mediating between various coalitions of internal and external actors and establishing controls to ensure that organizational effort is directed toward achieving the goals that the dominant coalition has set". In the case of parliaments, coalitions can be seen as composed by political parties in order to be able to take power of the house.

The functioning of the boards also correspond to the administrative boards of corporations pointed out by scholars in the field (VAN EES; GABRIELSSON; HUSE, 2009). The board does not base its decision-making in a general calculus that takes

\footnotetext{
${ }^{3}$ Retrieving the dichotomy between ownership and control.

${ }^{4}$ Besides the existence, from a ontological view point, the parliament, from a functional view point, exists while is gathered - "Parliament is not yet either an institution or a body: it is an occasion" (POLSBY, 1975, p. 290)
} 
into consideration all possible consequences for its decisions. It usually operates in a problem occurrence modus operandi. Where an issue is detected, the board starts the search for solutions, which usually is closed as soon as a satisfactory solution is found (HENDRY, 2002, 2005). In such process, board members take advantage of routines and heuristic that offer available feasible solutions, as well as the procedures through which decision are to be implemented (OCASIO, 1999; ZAHRA; FilatotCheV, 2004). According to Polsby (1975),

[...] mostly, alternatives are sharply attenuated by customary practice. Deliberation is a process by which the proper customary solutions are invoked and legitimized, that is, found, not invented, and analogies between precedents and contemporary circumstances are discovered and certified (POLSBY, 1975, p. 273).

Where there is a conflict between board members, the solution is the result of a continuous political bargaining process (HUSE; RINDOVA, 2001; PEARCE, 1995).

Besides the similarity with corporation's administrative boards in their functioning aspects, in the case of parliaments it is difficult to reach a consensus about the best interest of the Institution due to own meaning of the word "parties", which is "be part of", one faction. Therefore, value issues need to be balanced according to the coalitions of stakeholders to be taken into account. The "best interest of the Institution" is defined and redefined constantly through a permanent political negotiation process. Conflict is inherent to the limitation of the available utilities, which generated the circumstance that the satisfaction of a given interest implies into the sacrifice of an opponent interest. One board inside the parliament is not simply the result of the will and intention of association between political parties, but an exercise in which every party seeks to adequate its interests, no coincident, to the needs of the Institution. This perspective is associated with one tenet of the governance concept - an interest intermediation system or a reference of the systemic and institutional conditions under which the exercise of power comes about.

Worthy to notice the difficulty of bearing in mind that the institutional interests do not withdraw the compromise of its members with this attempt, because there are concepts of justice, social function, duties and other responsibilities which have to be taken into account under moral and ethics umbrella. That means, yet the competence of the boards are strictly regulated, which is the case of the Brazilian Parliament, an eventual application of Law principles in the concrete case requires the observance of ethics and moral as requirements for legitimacy. These are the ethics-moral concepts that will beacon the framework for the collective interests. This is true because a direct assessment of the compliance of the decisions with the collective interest is unattainable. 
Another important dimension in the researches involving administrative boards is its composition. We hereby discuss about these issues in the perspective of the directorate boards. The acquaintanceship in the board while is a long-term relationship requires a continuing effort where the common objective should be projected over the members. According to Simões (2003, p. 49, free translation), from the roots of the classic Roman Law, "the exigency of perseverance in a given social agreement result in a need of good faith". Arrow (1974) mentioned ethics and morality as invisible institutions, which works as conscious and unconscious agreements likely to generate multiple benefices. Participating as a board member requires investing on time both working as a board member, and as trying to figure out the institution and its issues. Participation will be as desirable as the greater the reputation effect and the contribution of this for the representative career (POLSBY, 1975).

The presence of the representative in the board can be strongly motivated by personal issues. There is a differentiated status resulting from the possibility of having additional funds (staff, office etc), and more visibility (appearing more frequently on the media $=$ more votes $)^{5}$. However, we can expect that board members have higher sensibility to the media. And it could happen either due to higher exposition, or by the fact that it is easier to focus in an individual rather than on the parliament as a whole. The increasing pressure exerted by society also contributes to the aversion of the members to make any decision that is likely to cause negative reactions from the media.

It is also not possible to identify if the size of the boards has impact on their performance ${ }^{6}$. Adams, Hermalin, and Weisbach (2010) pointed out a mathematical way ${ }^{7}$ for measuring the balance between more or less members in a corporation administrative board. Having larger tables is a almost natural consequence of the

5 The desire to have a place at the board exclusively for status issues and the lack of conscience about intrinsic responsibilities are damaging factors that highly contribute to leaving aside the collective interest.

6 Adams, Hermalin, and Weisbach (2010) point out a survey carried out with 81 enterprizes revealed a tendency to maintaining the size of their administrative boards. In1935, the average was of 11 members; in 1960, 15, and in 200011 again. Their research also suggest that a tendency of homogenizing these boards due to the standard deviation observed in the period (1935-2000), which goes from 5.5 to 2.7 .

7 Given: $C(n)$ - the cost of having $n$ members; $s p$ - the probability of a given member points out an issue, where $s$ is a measurement of institutional simplicity and $p$ is constant, we have that the Institution chooses the number of members in order to maximize (1) $\left.91-(1-s p)^{n}\right)-C(n)^{*}$ The cross partial derivative of (1) with respect to $s$ is $n$ and: $(2)(1-s p)^{n-1} p+n(1-s p)^{n-1} \log (1-s p) p$. Which has the same meaning of (3) $1+$ nlgo $(1-s p)$. If $s p>0,632$ or to $n$ larger enough, the marginal return of increasing the amount of members is decreasing in relation to the simplicity of the Institution. Hall, Johnson, and Haas (1967) affirmed the organization's complexity indicator is given by the degree of internal segmentation, measured by the general division of the work, specific division of the work, hierarchical differentiation and special dispersion. * Without loosing generalization, the probability of an existent problem multiplied was normalized and multiplied by the benefice of amending it to 1 . 
fact that social groups need progressively of coalitions to keep the stability in larger groups (DUNBAR, 1998).

Taking into account vertical and horizontal dimensions of governance proposed by Roe (2005), we can assume that parliaments realities become closer to the vertical one. The horizontal dimension of governance relates to controls exerted by organs and peers in the same hierarchical level. In the vertical dimension, mainly a higher-level organ in the hierarchy exerts the control. It is the kind of disperse property where there is no predominant actor. In such situation, the main objective of the governance is to ensure that the board and the directors act according to the institution best interest, besides being competent enough for managing it. Once we assume that this alignment doesn't come about spontaneously (agency problem), there is a need of creating institutional mechanisms for doing so.

In the particular case of the parliaments the alignment is ensured through regulations and by act of the Constitution. If we consider, even when distributive justice principles are in place, the existence of a predominant actor (political party or a coalition of parties), the horizontal dimension of the governance is visible in which institutional artifacts and mechanisms are set down to mitigating self-interest actions of the dominant group. The boards face the challenge of establishing a equity relation between the elements quantitatively and qualitatively unequal, that means majority and minority, without loosing, however, the golden rule on the preponderance of collective decisions of the majority decisions. Simões (2003) recalls the Anglo-Saxon Law to recognize the existence of a kind of fiduciary relationship between majority and minority in the exercise of power by the majority. The later has the responsibility of ensuring by the minority interests under the risk of, in the case of violation of this fiduciary right, having the abrogation of the deliberation.

Parliaments are places where the general will is formed, which reinforce the expectation that the acting of the institution is legitimate. The tenets that rules governance, in parliament houses, are provided of strong normative content clearly turned to the insurance of the minorities' participation ${ }^{8}$. Only in this way its functioning can be regarded as legitimate. According to Stanfield and Carroll (2004), power has to do with legitimacy, which means acting according to dominant rules and regulations and with transparency. This perspective also relates to the democracy dimension, because in a democratic environment - assumption of the parliamentary boards functioning - no actor should be able to intervene in order to revert the results of the formal process. Every interest should be equally submitted to competition in what has called by Przeworski as institutionalization

${ }^{8}$ The Stature of the Brazilian Senate, for instance, on its final part sets down the "General Principles of the Legislative Power", of normative content and turned to ensure the legitimacy in the elaboration of the 'legal norm'. 
of the uncertainty (PRZEWORSKI, 2000). Given such circumstances, in the boards of parliaments, more than that in the administrative boards of private companies, the formation of the collective will should come about by the vote, with the manifestation of each and "the votes are blended as support for the deliberation" (SIMÕES, 2003, p. 20, free translation).

It is worthy to highlight that these rules (institutional artifacts and mechanisms) transcend the efficiency of the management as it involves cultural and political aspects under which the practice of the governance is configured (NORTH, 1990). Components such as the level of the intensification of the political debate; the existence predominant coalitions; shared beliefs; social expectations; rules of social cohesion; regimental rules converge toward this structural configuration of the governance in parliaments. We also have to bear in mind "democratic governance does not lead to good governance. At best, it provides the basis for it" (AGERE, 2000, p. 94).

The theoretical framework aimed to demonstrate similarities and differences between legislative and company's administrative boards in order to offer a overall understanding about the role of the boards in the governance system of legislative houses. We stressed the legislative board as the locus of mediation between political and administrative, fundamental and present dichotomy of the legislative public administration. For this reason, we hereby undertake a two-dimensions classification of legislative houses according to the role of their boards.

\section{Methods}

This investigation uses the comparative approach with the help of quantitative methods for collecting and analyzing data, though some analytical methods could be regarded as qualitative. Data was collected by structured questionnaires in which the respondent provided information about the identification of the institution and eleven close-ended questions in which they could provide some additional comments.

We sent 271 questionnaires to House of Representatives or equivalents, and to Senates or equivalents in Portuguese, English, Spanish, and French. The universe of the respondents was based on the list of members of the Interparliamentary Union (IPU). The number of returned questionnaires was 32 from 31 countries, which represented a response rate of $11 \%$. In terms of continents, the sample comprises information from 22 Europeans countries, six Americans, two Asians, and one African. From the 32 legislative houses, 13 corresponded to unicameral parliaments (Portugal, Maldives, Luxemburg, Guatemala, Georgia, Ghana, Finland, Estonia, Croatia, Costa Rica, Chipper, Bulgaria e Andorra), eight are of Chamber of Deputies 
(Germany/Bundestag, Argentina, Bolivia, Canada/House of Commons, Slovenia, France, Poland, and the United Kingdom), seven corresponded to the Senate / High Chamber or Federal Council (Germany/Bundesrat, Belgian, Byelorussia, Canada, Chile, Italy, and Japan), three are of countries that have bicameral systems and whose answers referred to the Parliament (Austria, Bosnia e Herzegovina e Ireland/ Houses of the Oireachtas).

The questionnaire generated discreet quantitative variables, and nominal qualitative variables. The first section of the questionnaire, which aimed to the identification of the respondent, contributed to the understanding of the organizational form of each legislative house theme scarcely explored in the literature. Focusing on the institutional aspects, the research develops a dialog with classical studies, such as Polsby (1968), who analyzed the institutionalization process of the United States Congress; and Huitt (1979), who attempted to assimilate Congress to the Organization Theory. It is clear that in both cases the assumption that both the administrative organization, and the institutional configuration affect the political system, and this is the relevance of their studies. It is from Polsby (1968, p. 165) the following statement: "it is hard - indeed for the contemporary observer, impossible - to shake the conviction that the House's institutional structure does matter greatly in the production of political outcomes".

Bearing in mind the adopted research protocol - structured questionnaire sent to respondents in the form of census with no control of responses - the sample could be classified as accidental, which makes generalization a bit harder. The literature, however, regards this type of approach as a valid one because it deals with a small population and because of the researchers' profile, all experienced officers of the Legislative Power, and having discretion for judging the validity of the findings (BARBETTA, 2008). The research approach is the descriptive one with data organization, presentation, and systematization. The focus is oriented towards the governance concept and its transposition to the public sphere starting from a critical thinking about its assumptions.

In the universe of the parliaments, the emphasis is placed on the separation of the political control from the administrative control. Given that the Directorate Board plays a central role in this relationship politics versus administrative, this investigation is based on a spatial model proposed by the researchers, which consists in categorizing governance of the responding institutions according to the politics and administrative perspectives identified in the declaration of competencies of each respective directorate boards. Such perspectives were combined into four scenarios, as follows for proposing a good definition of administrative and politics perspectives. What we consider in each is the political-partisanship articulation 
(political perspective), in which we focus on what defines the organization's aims, and budget (administrative perspective):

- Scenario 1: weak/absent/timid governance, when the declaration of competences of the directorate board is reduced in terms of the number of competences, semantically generic and do not differentiate political from administrative activities.

- Scenario 2: politicized governance, when board directorate set of tasks besides the attributions related to conducting the legislative process and the political-partisanship articulation (political perspective), with more emphasis on those activities related to strategy such as budget activities (administrative perspective). In such cases, and in general, there is a director body with limited autonomy for performing diverse administrative tasks. However, the main decisions are taken by the board and, therefore, strongly influenced by political orientations.

- Scenario 3: managerial/strategic/supervision governance, where in the set of tasks performed by the Directorate Board there is a prevalence of tasks related to conducting the legislative process, and to the politicalpartisanship articulation (political perspective). In this case, and in general, one director body with wide autonomy for performing administrative tasks with power to make decision based on efficacy, efficiency, and effectiveness (administrative perspective).

- Scenario 4: hybrid/strong governance, when in the Directorate Board set of tasks there is a balance between political and administrative competences. In this case, the composition of the board can admit the presence of the administrative area for representation and with voting power.

Based on the semantic content of the declared competences, we ranked each competence by assessing their association to political and administrative perspectives according to the following scale: 0 - absence of the factor; 0,5 factor partially present; 1 - factor clearly present. This analysis resulted into a two-dimensions matrix in which the administrative and political perspectives are combined in maturity quadrants for representing the scenarios above. The classifications were carried out by each author and after that consolidated in a faceby-face meeting in order to mitigate subjectivity. 


\section{Results}

\section{Structures and designation}

The title of the parliamentary boards per si is embedded in the administrative versus politics dichotomy, which is explored by the model we use in this investigation. There are names that suggest the predominance of one of the roles above the other. The administrative role for instance is quite visible in the cases of "Parliamentary Administration" (Austria); "Standing Committee on Internal Economy, Budgets and Administration" (Senate of Canada); "Board of Internal Economy" (Chamber of Canada); "Comisión de Régimen Interior" (Senate of Chile)". More generic designations, such as "Secretariat" (Bundesrat, Germany), "Presidium" (Byelorussia), "Collegium" (Bosnia and Herzegovina) points toward the political perspective as a prevalent function. The use of other denominations is still an indication of the heterogeneity of practices found in parliaments: "Sindicatura" (Andorra), "Bureau" (Senate of Belgium), "Directiva" (Bolivia), "Secretary General" (Slovenia e Estonia), "Office Commission" (Finland), "Comisión Permanente" (Guatemala), "Committee on Rules and Administration" (Japan).

Looking at the parliament's structures we also see huge heterogeneities. There are elected boards (as Argentina and Brazil), and boards composed by members from other parts of the government, such as Belgium (composed, among other members, by the presidents of the political groups representing permanent commissions). In countries of parliamentary tradition, such as Canada, the board is composed by the Speaker, and by two other members of the government, one member of the opposition (usually the leader of the opposition), and additional members in order to ensure a balance between government and opposition representatives (distributive justice). The main tenets of the distributive justice can also be applied to ensure the representation of the minorities in presidential systems, such as the Brazilian case.

There are boards with generic competences (i.e. the United Kingdom, Costa Rica, Austria), and boards with specific competences (i.e. Brazil, Croatia, Finland). In the Brazilian case, specific functions are dedicated to certain members of the board (first secretariat, second vice presidency etc). 
Table 1 - Boards: composition and size

\begin{tabular}{|c|c|c|c|c|}
\hline \multirow{2}{*}{ Legislative House } & \multicolumn{2}{|c|}{$\begin{array}{c}\text { Composition of } \\
\text { the Board }\end{array}$} & \multirow{2}{*}{$\begin{array}{l}\text { Size of the } \\
\text { Board }\end{array}$} & \multirow{2}{*}{$\begin{array}{c}\text { Board / Total of } \\
\text { Representatives } \\
(\%)^{a}\end{array}$} \\
\hline & $\begin{array}{l}\text { Only } \\
\text { MPc }^{c}\end{array}$ & $\begin{array}{l}\text { MP } \\
\text { e + }\end{array}$ & & \\
\hline \multicolumn{5}{|l|}{$\begin{array}{l}\text { Chamber of Deputies or } \\
\text { equivalents }\end{array}$} \\
\hline Germany & & $x$ & 69 & 11 \\
\hline Andorra & $x$ & & 4 & 14 \\
\hline Argentina & $x$ & & 4 & 2 \\
\hline Bolivia & $x$ & & 7 & 5 \\
\hline Bosnia e Herzegovina & $x$ & & 9 & 21 \\
\hline Canada & $x$ & & 7 & 2 \\
\hline Costa Rica & $x$ & & 3 & 5 \\
\hline Croatia & & $x$ & 6 & 4 \\
\hline Slovenia & & $x$ & 14 & 16 \\
\hline \multicolumn{5}{|l|}{ Estonia } \\
\hline Finland & $x$ & & 7 & 4 \\
\hline France & $x$ & & 22 & 4 \\
\hline Ghana & & $x$ & 6 & 3 \\
\hline Guatemala & $x$ & & 9 & 6 \\
\hline Ireland & $x$ & & 11 & 7 \\
\hline Luxemburg & & $x$ & 11 & 18 \\
\hline Macedonia & $x$ & & & \\
\hline Portugal & & $x$ & 9 & 4 \\
\hline United Kingdom & $x$ & & 6 & 1 \\
\hline \multicolumn{5}{|l|}{ Senates or equivalents } \\
\hline Germany & $x$ & & 69 & \\
\hline Belgium & $x$ & & 17 & 24 \\
\hline Byelorussia & $x$ & & 7 & 11 \\
\hline Bosnia e Herzegovina & $x$ & & 9 & 60 \\
\hline Canada - Senate & & $x$ & 15 & 14 \\
\hline Chile & $x$ & & 7 & 18 \\
\hline Ireland & $x$ & & 11 & 18 \\
\hline Italy ${ }^{b}$ & $x$ & & 20 & 6 \\
\hline Japan & $x$ & & 25 & 10 \\
\hline
\end{tabular}

Source: Developed by the authors.

a. Values rounded. b. Data about the Italian Senate consulted on its website. c. MP - member of Parliament.

The analysis of the competences of the boards reveals diversity. Some demonstrates competencies exclusively dedicated to political activities. Other demonstrate only administrative competences, and, yet, other hybrid 
competences between administrative and political. The authors has classified independently the competences and later on checked classifications, in order to reduce subjectivity. Some samples of administrative competences: "Under the Parliament of Canada Act, the Board has legal authority to "act on all financial and administrative matters respecting the House of Commons, its premises, its services and its staff; and the Members of the House of Commons"; "The structure, composition of staff, titles of positions and support staff positions, salary scale and salary rates of the Chancellery of the Riigikogu shall be established by the Board of the Riigikogu", "The Secretary of Parliament shall direct the Parliamentary Staff Service and administer its operations, and adopt the Rules of Internal Conduct for the Parliamentary Staff Service". Samples of political competences: "The Secretary of Parliament, as needed, assists the Speaker of Parliament in the preparation of parliamentary sessions"; "The Board also approves the statutes of the Chancellery of the Riigikogu establishing rights and main functions of the Chancellery of the Riigikogu, and the organisation of management and the competence of structural units thereof"; "Standing Order 148(2) further require that when the Board has reached a decision concerning any budget presented to it, the Speaker shall lay upon the Table the record of the Board's decision".

Administrative competences are sometime presented in generic form (i.e. Senate of Canada: the committee is responsible for the good internal management of the Senate. Good internal management meaning a proficient management, flexible, fair and transparent; with appropriate policies and programs; adequate levels of quality including high qualified personnel, appropriate and regular accountability mechanisms). Others are presented in details (the case of Brazilian Legislative Assemblies and Municipal Chambers). Ireland represents a situation in which the Board has only administrative competencies, however of strategic level: the role of the Commission is strategic instead of operational. The Parliament daily activities are of responsibility of the General-Secretariat and its staff.

From the Chamber of Deputies or similar, seven (28\%) did not declared the existence of Directorate Board or equivalent. In some of these cases they indicated all representatives as member of the directorate body (i.e. Republic of Maldives). Other indicated the centralization of all competences in the hands of the President (i.e. Bulgaria). Eight declared that the Directorate Board or equivalent is comprised by representatives and member of other nature, such as civil servants. Seventeen declared that the directorate board is exclusive composed by representatives. There are the cases in which the general-secretariat is member of the board, but he/she is not a representative, and this office is filled as a result of a mandate (i.e. Estonia). In five parliaments, the Directorate Board or equivalent is composed by 
more than $10 \%$ of the total of members being Bosnia and Herzegovina located at the superior limit whose Board is composed by $21 \%$ of the members of the parliament.

Canada's Senate stands out as the only example of the category in which representatives compose the Directorate Board alongside with member of other nature in one board of 15 members. A prima facie comparison with the board of the representative reveal that in Senate Houses the boards are larger in which the percentage varies from $6 \%$ to $60 \%$. In this way, only $49 \%$ of the variation in the number of member of the board is explained by the variation in the number of representatives, as Table 2 demonstrates.

Table 2 - Members of the Board/Representatives

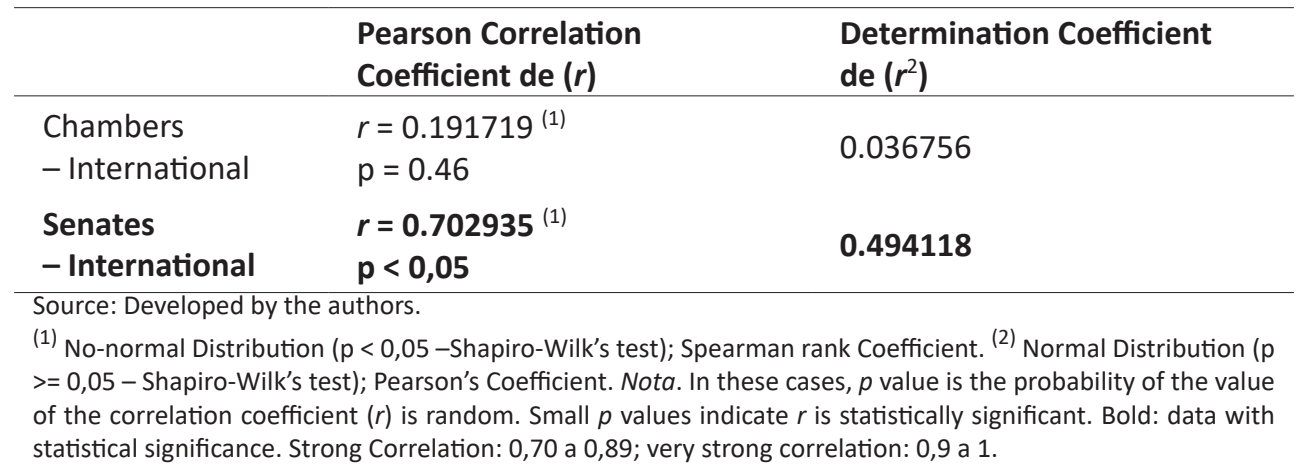

Besides the average size of the parliaments do not contribute to the clarification of the house's functioning, curiously its value $[14,36]$ is still among the group called sympathetic ${ }^{9}$. It involves for instance to ask individuals to remember someone whose death has caused great pain for them [11-12], or to friends and fellows with whom they have had contact once in a while [10-15] (DUNBAR, 1998, p.77). For Dunbar (1998, p. 77), "it is striking that groups of this size are common in situations where very close co-ordination of behaviour is required: juries, the inner cabinets of many governments, the number of apostles, the size of most sport teams".

Adams, Hermalin, and Weisbach (2010) pointed out as another problem the fact that structures of governance are highly endogenous, besides the fact that the need for the existence of the boards is endogenous (interregnums, parliament in vigilando). In the case of the parliaments, the endogeneity issue is yet more crucial. In the great majority of the cases, boards are exclusively composed by

\footnotetext{
${ }^{9}$ Sympathy group, the number of people with which an individual can simultaneously have an empathic strong relationship, which means, for Dunbar (1998) people that you know intimately and that you would feel very sorry for anything that affect them.
} 
representatives and when they are increased in number, these members come from the administrative sphere. The good practice of governance in the private sector suggests the need for the "independent councilor", having as a starting point the premises values of autonomy and freedom. Nonetheless, for its own specificity and being a mixed-body in charge of political and administrative conduction, and the issue of members being elected by peers, it would be unusual having a board composed exclusively by external members.

\section{Model}

La Porta et al. (1998) suggested the influence of the legal and juridical tradition of one country (consuetudinary and positive) on the board functioning. In many studies about administrative boards, scholars try to understand if the role and structure of them impact organizational performance. In the case of parliaments, according to conceptual aspects presented as well as by the fact that there are no consentaneous productivity parameters for assessing their performance, we advocated towards an assessment model in which we are able to figure out in what extent the board has its role more focused on management or on the political leadership.

In this line of thinking, the assessments provided by the authors, which have been done according to the procedures described in the method section, we have the results presented on Table 3. Aiming to balance the occasional deviations of the amount of competences, which is likely to vary across parliaments, we used the weighted average in each perspective (administrative and political) for defining the parameters of the model. The result is presented in Figure 1.

Table 3 - The average of the scores for each competency

\begin{tabular}{|c|c|c|c|}
\hline \multirow{2}{*}{ Country } & \multirow{2}{*}{$\begin{array}{c}\text { Amount of } \\
\text { Competences }\end{array}$} & \multicolumn{2}{|c|}{ Average } \\
\hline & & Adm. & Pol. \\
\hline Andorra & 6 & 0,36 & 0,64 \\
\hline Austria & 1 & 0,33 & 0,67 \\
\hline Byelorussia & 12 & 0,17 & 0,72 \\
\hline Bolivia & 5 & 0,20 & 0,80 \\
\hline Bosnia and Herzegovina & 1 & 0,33 & 0,00 \\
\hline Brazil - Chamber of Deputies & 29 & 0,28 & 0,72 \\
\hline Brazil-Senate & 30 & 0,00 & 1,00 \\
\hline
\end{tabular}




\begin{tabular}{|c|c|c|c|}
\hline \multirow{2}{*}{ Country } & \multirow{2}{*}{$\begin{array}{c}\text { Amount of } \\
\text { Competences }\end{array}$} & \multicolumn{2}{|c|}{ Average } \\
\hline & & Adm. & Pol. \\
\hline Bulgaria & 2 & 0,33 & 0,67 \\
\hline Canada Chamber & 9 & 0,63 & 0,37 \\
\hline Canada Senate & 3 & 0,33 & 0,44 \\
\hline Chile & 4 & 0,96 & 0,04 \\
\hline Costa Rica & 3 & 0,28 & 0,72 \\
\hline Croatia & 13 & 0,33 & 0,67 \\
\hline Slovenia & 15 & 0,43 & 0,48 \\
\hline Estonia & 2 & 0,58 & 0,42 \\
\hline Finland & 9 & 0,63 & 0,30 \\
\hline France & 3 & 0,44 & 0,56 \\
\hline Guatemala & 6 & 0,39 & 0,61 \\
\hline Ireland & 11 & 0,33 & 0,67 \\
\hline Italy & 5 & 0,27 & 0,73 \\
\hline Japan & 1 & 0,33 & 0,67 \\
\hline Luxemburg & 3 & 0,72 & 0,28 \\
\hline Poland & 2 & 0,33 & 0,67 \\
\hline United Kingdom & 3 & 0,33 & 0,67 \\
\hline
\end{tabular}

\begin{tabular}{l|c|c}
\hline Weighted Average & 0,32 & 0,66 \\
\hline \multirow{2}{*}{ Amplitude } & 0,00 & 0,00 \\
\cline { 2 - 3 } & 0,96 & 1,00 \\
\hline
\end{tabular}

Source: Data Analysis, developed by the authors.

Interestingly, the Hybrid quadrant stands out parliaments of whose countries adopt the parliamentary system of government or constitutional monarchy (commonly ruled by an oligarchical parliamentary) in which the prime minister is the presiding and actual head of the government and head of the executive branch. A parliamentary system is a system of democratic governance of a state in which the executive branch derives its democratic legitimacy from, and is held accountable to, the legislature (parliament); the executive and legislative branches are thus interconnected. Based on that, it is reasonable to think that a parliamentary scenario 
tend to balance political and administrative dimensions in the parliament. This fact constitutes a possible explanation for the prevalence of parliamentary systems in the Hybrid quadrant.

\section{Figure 1 - Governance of each Parliament involved in the investigation}

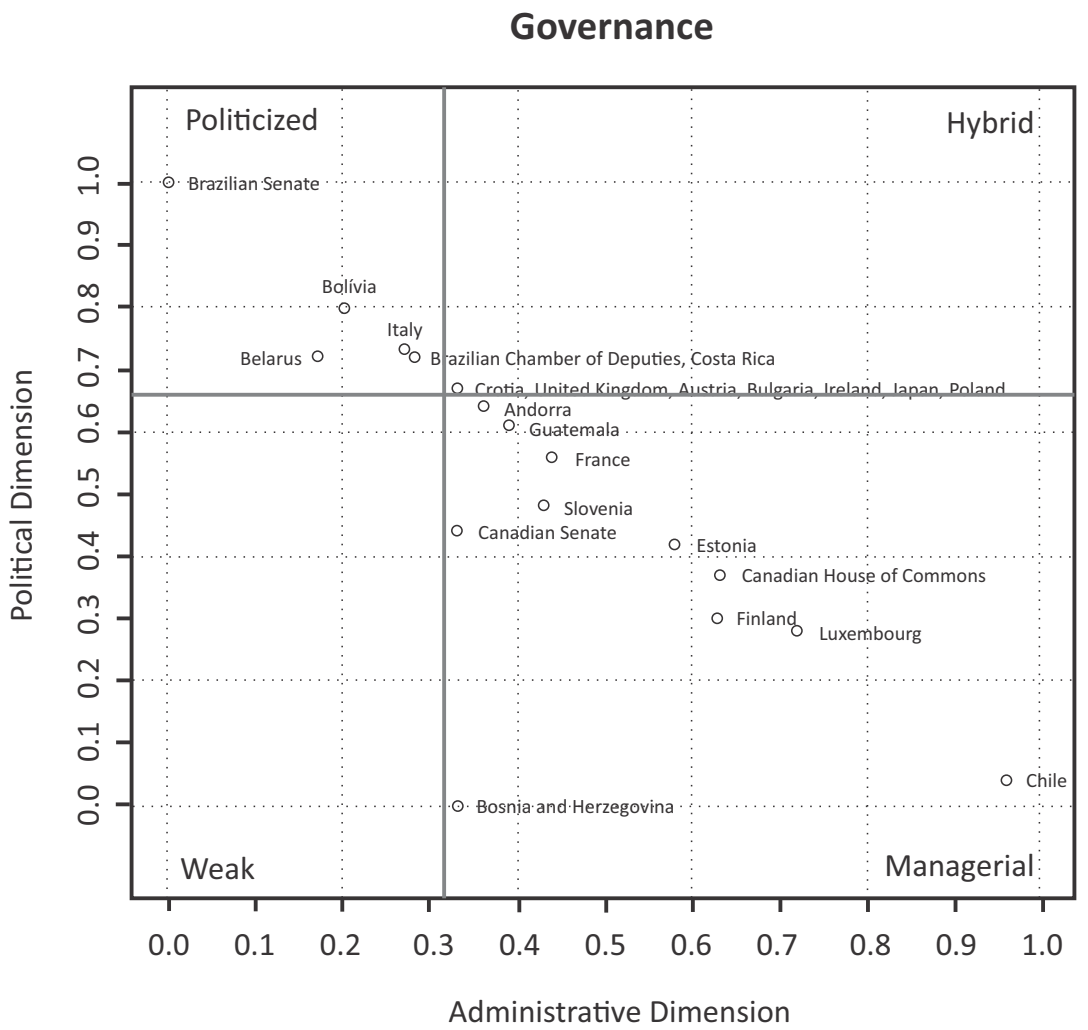

Source: Data analysis, developed by the authors.

In presidential systems, the executive branch is independent of the legislature. While in the parliamentary system the executive branch arises from the correlation of forces among the parties elected to Parliament, in presidentialism the executive branch is derived from the direct election of the president by the citizens. Agreements among parties (usually in order to hold positions in government) and alliances between political forces (hardly around ideas or programs) to achieve certain goals are common practice in this system of government. Especially in multiparty systems, in which there are more than two relevant parties vying for election and occupying seats in Congress, hardly the President's party will have an ample majority in parliament to approve its projects and implement its policies. The political observer Fernando Henrique Cardoso hit the fly when he said that, however 
well it has been voted President-elect its electoral capital ("votes") must be the next day, converted into political capital ("support"). This phenomenon seems to require a more politicized role of parliament, as it highlights the political dimension, which corroborates the fact that presidential systems prevail in the Politicized quadrant.

\section{Final thoughts}

If Parliaments are institutions scarcely studied in its institutional specificities, the parliamentary system of governance is therefore practically unknown in the academic milieu. This article has relevance because it intends to propose considerations about the governance in the Legislative Power, and for so doing from a cross-sectional investigation involving different realities.

In this study, we present an attempt of dialoguing with the field of institutional theory with some emphasis on the literature on corporate governance. Starting from this literature review we identified similarities and differences between private sector corporate governance, and the governance of the Legislative Power. The main difference we found is the reference to the 'common being' as ethicnormative framework in the decision-making process of parliamentary boards. In the area of legislative houses, the endeavor for defining this common being is of great complexity, and it is almost impossible to have a clear definition of it. The principal is almost a myth. Accomplishing a unitary will from the debacle of the predetermined desires (aspirations of several different political parties) is a very hard task. Many times what does happen is the prevalence of a no-consensual decision of the majority over the minority will.

The methodological approach used a comparative and quantitative strategy in which some qualitative procedures where used as well. The findings reveal great heterogeneities demonstrating that each parliament comes up with a specific solution for its governance problems. Such heterogeneity suggests that the right question is not "how is the perfect board", but, yes, "how parliaments can evolve in the configuration and functioning of its directorate boards." There is a need for speculating that the role of the governance system is to ensure that the agents fulfill the wishes of the principal with loyalty and diligence. We also assume that the proposed model encompasses the fact that there is not optimal solution for the board, in the extent that the structures of governance involve a given type of board, which functions according to some paradigm, with a peculiar system for allocating benefits and having to be responsive to the whole set of stakeholders.

From the finds we developed a two-dimensions model for the classification of the parliamentary boards. The majority of the boards were classified in the 
managerial quadrant, demonstrating strong connection between those boards and the finalistic dimension of the parliaments, i.e. its political perspective (legislative process + political-partisan articulation). The parliamentary boards of Croatia, the United Kingdom, Austria, Bulgaria, Ireland, Japan and Poland were classified in the hybrid quadrant, demonstrating balance between political and administrative activities. The boards of Brazil (Senate and the Chamber of Deputies), Bolivia, Italy and Byelorussia were seen as "politicized", i.e. a situation in which the board besides its political competences also exerts administrative competences. Such practices is not recommended by the literature about corporate governance, for which it is most adequate that a body with the role of a administration board carries on more strategic functions and less closer to the organizations routine. 


\section{References}

Adams, Renee; Hermalin, Benjamin E.; WeISBACH, Michael S. The role of boards of directors in corporate governance: a conceptual framework \& survey. Berkeley: Center for Responsible Business, 2010.

AGERE, Sam. Promoting good governance: principles, practices and perspectives. Vol. 11. Commonwealth Secretariat, 2000.

Aguilera, Ruth V.; Cuervo-CAZurRA, Alvaro. Codes of good governance worldwide: what is the trigger?. Organization Studies, v. 25, n. 3, p. 415-443, 2004.

AgUILERA, Ruth V; JACKSON, Gregory. The cross-national diversity of corporate governance: dimensions and determinants. Academy of management review, $\mathrm{v}$. 28, n. 3, p. 447-465, 2003.

ARROW, Kenneth Joseph.. The limits of organization. New York, USA: WW Norton, 1974.

BARBEtTA, Pedro Alberto. Estatística aplicada às ciências sociais. Florianópolis: Ed. UFSC, 2008.

Bergue, Sandro Trescastro. Modelos de gestão em organizações públicas: teorias e tecnologias para análise e transformação organizacional. Caxias do Sul: Educs, 2011.

BLAIR, Margaret M. Ownership and control: rethinking corporate governance for the twenty-first century, 1995.

BRAgA, Ricardo de João; SATHLER, André Rehbein; MIRANDA, Roberto Campos da Rocha. The institutionalisation of the Brazilian Chamber of Deputies. The Journal of Legislative Studies, v. 22, n. 4, 2016.

BRASIL. Tribunal de Contas da União. Referencial básico de governança. Brasília: TCU, 2013.

CAPRON, Laurence; GUILLÉN, Mauro. National corporate governance institutions and post-acquisition target reorganization. Strategic Management Journal, v. 30, n. 8 , p. 803-833, 2009.

DUNBAR, Robin. Grooming, gossip, and the evolution of language. Harvard: Harvard University Press, 1998.

Enrione, Alfredo; MAZZA, Carmelo; Zerboni, Fernando. Institutionalizing codes of governance. American Behavioral Scientist, v. 49, n. 7, p. 961-973, 2006.

HALL, Peter A.; TAYLOR, Rosemary C. R. As três versões do neo-institucionalismo. Lua Nova, v. 58, p. 193-223, 2003.

HALL, Richard H.; Johnson, Norman J.; HAAS, J. Eugene. Organizational size, complexity, and formalization. American Sociological Review, v. 32, n. 6, p. 903-912, 1967. doi: $10.2307 / 2092844$.

HENDRY, John. The principal's other problems: honest incompetence and the specification of objectives. Academy of Management Review, v. 27, n. 1, p. 98-113, 2002. 
HENDRY, John. Beyond self-interest: agency theory and the board in a satisficing world. British Journal of Management, v. 16, n. 1, p. 55-63, 2005.

HUITT, Ralph K. Lyndon B. Johnson and Senate Leadership. In: LIVINGSTON, William S.; DODD, Lawrence C.; SCHOTT, Richard L. (Eds.) The Presidency and the Congress: a shifting balance of power? Austin: Lyndon B. Johnson School of Public Affairs. 1979. p. 253-64.

HUSE, Morten; RINDOVA, Violina P. Stakeholders' expectations of board roles: the case of subsidiary boards. Journal of Management and Governance, v. 5, n. 2, p. 153-178, 2001.

Instituto Brasileiro de Governança Corporativa (IBGC). Código das melhores práticas de governança corporativa. 4 ed. São Paulo: Instituto Brasileiro de Governança Corporativa, 2009.

JACOBSEN, Thorkild. Primitive democracy in ancient Mesopotamia. Journal of Near Eastern Studies, v. 2, n. 3, p. 159-172, 1943.

KEANE, John. Vida e morte da democracia. São Paulo: Edições 70, 2010.

LA PORTA, Rafael et al. Law and finance. Journal of Political Economy, v. 106, n. 6, p. 1113-1155, 1998. doi: 10.1086/250042.

MARCH, James G.; OLSEN, Johan P. Democratic governance. New York: The Free Press, 1995.

Matias-PereirA, José.. Governança no setor público. São Paulo: Editora Atlas, 2010. NORTH, Douglass C. Institutions, institutional change and economic performance. Cambridge: Cambridge University Press, 1990.

OCASIO, William.. Institutionalized action and corporate governance: the reliance on rules of CEO succession. Administrative Science Quarterly, v. 44, n. 2, p. 384-416, 1999.

PEARCE, John A. A structural analysis of dominant coalitions in small banks. Journal of Management, v. 21, n. 6, p. 1075-1095, 1995. doi: 10.1177/014920639502100604.

PolsBy, Nelson W. The institutionalization of the US House of Representatives. American Political Science Review, v. 62, n. 1, p. 144-168, 1968.

. Legislatures. In: GREensteIn; Fred I; PolsBy, Nelson W. (Eds.). Handbook of Political Science. Reading, MA: Addison Wesley, 1975. p. 257-319.

PRZEWORSKI, Adam. Democracy and development: political institutions and wellbeing in the world, 1950-1990. v. 3. Cambridge: Cambridge University Press, 2000.

RoE, Mark J. Corporate governance: political and legal perspectives. v. 8. Edward Elgar Publishing, 2005.

RosSONI, Luciano; MACHADO-DA-SILVA, Clóvis L. Institucionalismo organizacional e práticas de governança corporativa. Revista de Administração Contemporânea, v. 14, p. 173-198, 2010.

SANTOS, Maria Helena de Castro. Governabilidade, governança e democracia: criação de capacidade governativa e relações Executivo-Legislativo no Brasil pósconstituinte. Dados, v. 40, n. 3, 1997. 
SIMÕES, Paulo Cesar Gonçalves. Governança corporativa e o exercício do voto nas SA. Rio de Janeiro: Editora Lumen Juris, 2003.

StANFIELD, James Ronald; CARRolL, Michael C. Governance and the legitimacy of corporate power: a path for convergence of heterodox economics? Journal of Economic Issues, p. 363-370, 2004.

VAN EeS, Hans; GABRIELSSON, Jonas; HuSE, Morten. Toward a behavioral theory of boards and corporate governance. Corporate Governance: An International Review, v. 17, n. 3, p. 307-319, 2009.

WEINGAST, Barry R; MARSHALL, William. The industrial organization of Congress; or, Why Legislatures, like firms, are not organized as markets. Journal of Political Economy, v. 96, n. 11, 1988.

ZAHRA, Shaker A; FILATOTCHEV, Igor. Governance of the entrepreneurial threshold firm: a knowledge-based perspective. Journal of Management Studies, v. 41, n. 5, p 885-897, 2004.

ZATTONI, Alessandro; CuOMO, Francesca. Why adopt codes of good governance? A comparison of institutional and efficiency perspectives. Corporate Governance: An International Review, v. 16, n. 1,p. 1-15, 2008.

\section{André Rehbein Sathler Guimarães}

Possui doutorado em Filosofia pela Universidade Federal de São Carlos (UFSCar). Atualmente é Assessor Legislativo e docente do mestrado profissional em Poder Legislativo do Centro de Formação, Treinamento e Aperfeiçoamento da Câmara dos Deputados. Contato: andre.sathler@gmail.com

\section{Fabiano Peruzzo Schwartz}

Possui doutorado em Engenharia de Sistemas Eletrônicos e de Automação pela Universidade de Brasília (UnB). Atualmente é Coordenador do Programa de Pós-Graduação do Centro de Formação, Treinamento e Aperfeiçoamento da Câmara dos Deputados, e docente do mestrado profissional em Poder Legislativo. Contato: fabiano.schwartz@camara.leg.br

\section{Ricardo Corrêa Gomes}

Possui doutorado pela Aston Business School (Reino Unido) e pós-doutorado pela Georgia State University (Estados Unidos). Atualmente é professor Associado II da Universidade de Brasília (UnB). Contato: gomesric.rg@gmail.com 
